\title{
Meningkatkan Prestasi Belajar IPS Materi Mengidentifikasikan Benua-Benua Dengan Metode Discovery Siswa Kelas VI Semester I SDN Lingkuk Bunut Kecamatan Janapria Tahun Pelajaran 2017/2018
}

\author{
Salam \\ Guru SDN Lingkok Bunut Kecamatan Janapria Kabupaten Lombok Tengah
}

\begin{abstract}
Abstrak. Berdasarkan hasil observasi dan data di SDN Lingkok Bunut, khususnya Kelas VI terdapat permasalahan yang dihadapi oleh siswa yaitu kurangnya motivasi dari diri siswa dalam mengikuti proses belajar mengajar mata pelajaran IPS, pernyataan tersebut didasarkan pula pada hasil nilai ulangan harian siswa pada mata pelajaran IPS yang cukup rendah dan daya serap siswa secara klasikal masih dibawah Kriteria Ketuntasan Minimal (KKM) secara klasikal yaitu 48,15\%. Secara rinci dari 27 siswa Kelas VI Semester I SDN Lingkok Bunut Kecamatan Janapria Kabupaten Lombok Tengah Tahun Pelajaran 2017/2018 yang terdiri dari 12 siswa laki-laki dan 15 siswa perempuan,yang mendapat nilai 80-100 adalah 2 siswa $(7,41 \%)$, yang mendapat nilai 70-79 sebanyak 11 siswa (40,74\%), yang mendapat nilai 60-69 sebanyak 3 siswa $(11,11 \%)$, yang mendapat nilai 40-59 sebanyak 11 siswa $(40,74 \%)$. Fakta ini menunjukkan bahwa siswa Kelas VI SDN Lingkok Bunut belum mencapai prosentase ketuntasan belajar secara klasikal yaitu 80\% sesuai dengan KKM yang telah ditetapkan. Disamping itu pengajar menyadari bahwa metode pembelajaran yang dilakukan masih bersifat abstrak karena dalam memberikan penjelasan dilakukan secara singkat dan hanya mengunakan satu buku sumber. Berdasarkan hasil diskusi antara pengajar dan teman sejawat dan refleksi terhadap masalah tersebut disepakati bahwa pemecahan masalah akan dilakukan dengan menggunakan menggunakan Metode Discovery. Penelitian ini menggunakan rancangan penelitian tindakan kelas yang terdiri dari dua siklus. Pada masing-masing siklus dilakukan tahap perencanaan, pelaksanaan tindakan, pengamatan, dan refleksi. Subyek penelitian menggunakan siswa Kelas VI Sekolah Dasar Negeri Lingkok Bunut Hasil penelitian dengan menggunakan Metode Discovery dapat melibatkan siswa secara aktif dalam pembelajaran, siswa dapat belajar mengajukan pertanyaan, mengembangkan pendapat, menghargai pendapat teman, dan belajar bekerjasama dengan teman, hal ini akan berpengaruh terhadap hasil belajar siswa menjadi lebih baik.
\end{abstract}

Kata Kunci : Meningkatkan Prestasi Belajar,Metode Discovery IPS

\section{PENDAHULUAN}

\section{Latar Belakang}

Dalam proses belajar mengajar guru menjadi pemeran utama dalam menciptakan situasi discopery yang edukatif, yakni interaksi antara guru dengan siswa, siswa dengan siswa dan denga sumber pembelajaran dalam menunjang tercapainya tujuan belajar. Untuk terwujudnya proses belajar mengajar seperti itu sudah tentu menuntut upaya guru untuk mengaktualisasikan kompetensinya secara professional, utamanya aspek metodologis. IPS sebagai salah satu bidang studi yang memiliki tujuan membekali siswa untuk mengembangkan penalarannya disamping aspek nilai dan moral, banyak memuat materi social bersifat hapalan sehingga pengetahuan dan informasi yang diterima siswa sebatas produk hapalan. Sifat pelajaran IPS tersebut membawa konsekuensi terhadap proses belajar mengajar yang didominasi oleh pendekatan ekspositoris, terutama guru menggunakan metode ceramah sedangkan siswa kurang terlibat atau cenderung pasif.
Dalam metode ceramah terjadi dialog imperaktif. Padahal, dalam proses belajar mengajar keterlibatan siswa harus secara totalitas, artinya melibatkan pikiran, penglihatan, pendengaran, dan psikomoto (keterampilan, salah satunya sambil menulis). Jadi, dalam proses belajar mengajar, seorang guru harus mengajak siswa untuk mendengarkan, menyajikan media yang dapat dilihat, memberi kesempatan untuk menulis dan mengajukan pertanyaan atau tanggpan sehinga terjadi dialog kreatif yang menunjukkan proses belajar mengajar yang Discopery. Situasi belajar seperti ini dapat tercipta melalui penggunaan pendekatan partiestoris.

Proses belajar mengajar mempunyai makna dan pengertian yang lebih luas dari pada pengertian mengajar, karena didalamnya tersirat satu kesatuan kegiatan yang tidakterpisahkan antara siswa yang belajar dna guru yang mengajar, yang terjalin dalam bentuk interaksi edukatif. Peran guru dalam pembelajarn IPS mempunyai hubungan erat dengan cara mengaktifkan siswa dalam belajar, terutama dalam proses pengembangan keterampilannya. 
Pengembangan keterampilan yang harus dimiliki siswa adalah keterampilan berfikir, keterampilan social dan keterampilan praktis. Keterampilan berfikir dikembangkan untuk melatih siswa berfikir logis dan sistematis melalui proses belajar mengajar dengan model pengembangan berfikir kritis, keterampilan social dan praktis melalui model dialog kreatif.Ketiga keterampilan tersebut dapat dikembangkan dalam situasi belajar mengajar yang Discopery antara guru dengan siswa dan siswa dengan siswa.

Permasalahan yang muncul di sekolah saat melaksanakan pembelajaran siswa dalam bidang IPS adalah kurangnya motivasi dari diri siswa dalam mengikuti proses belajar mengajar. Mereka kurang serius dalam memfokuskan diri mengikuti materi pembelajaran IPS.Hal ini muncul karena dalam pelaksanaan belajar mengajar guru lebih sering menggunakan buku sebagai sumber belajar, dimana guru hanya menggunakan metode ceramah saja dalam menjelaskan materi pembelajaran IPS.Tidak adanya media peraga atau contoh gambar yang merupakan sarana pengetahuan nyata bagi siswa.

Berdasarkan hasil observasi dan data di SDN Lingkok Bunut, khususnya Kelas VI terdapat permasalahan yang dihadapi oleh siswa yaitu kurangnya motivasi dari diri siswa dalam mengikuti proses belajar mengajar mata pelajaran IPS, pernyataan tersebut didasarkan pula pada hasil nilai ulangan harian siswa pada mata pelajaran IPS yang cukup rendah dan daya serap siswa secara klasikal masih dibawah Kriteria Ketuntasan Minimal (KKM) secara klasikal yaitu 48,15\%. Secara rinci dari 27 siswa Kelas VI Semester I SDN Lingkok Bunut Kecamatan Janpria Kabupaten Lombok Tengah Tahun Pelajaran 2015/2016 yang terdiri dari 12 siswa laki-laki dan 15 siswa perempuan,yang mendapat nilai 80-100 adalah 2 siswa $(7,41 \%)$, yang mendapat nilai 70-79 sebanyak 11 siswa $(40,74 \%)$, yang mendapat nilai $60-69$ sebanyak 3 siswa $(11,11 \%)$, yang mendapat nilai $40-59$ sebanyak 11 siswa $(40,74 \%)$. Fakta ini menunjukkan bahwa siswa Kelas VI SDN Lingkok Bunut belum mencapai prosentase ketuntasan belajar secara klasikal yaitu $80 \%$ sesuai dengan KKM yang telah ditetapkan.

Setelah kegiatan pembelajaran selesai peneliti mengadakan diskusi teman sejawat, hasil diskusi dengan teman sejawat ditemukan beberapa masalah yang terjadi dalam proses belajar mengajar, yaitu: (1) Kurangnya interaksi antara guru dan siswa. (2) Penguasaan guru tentang metode pengajaran masih berada dibawah standar, (3) Siswa cenderung pasif dan kurangnya motivasi siswa, (4) Metode yang digunakan dalam mengajar hanya ceramah, (5) Siswa cenderung menghafal bukan memahami materi pelajaran.

\section{Rumusan Masalah}

Berdasarkan uraian di atas, maka rumusan masalah dalam penelitian ini adalah: "Bagaimanakah Meningkatkan Prestasi Belajar IPS Materi Mengidentifikasikan BenuaBenuadengan Metode Discovery Siswa Kelas VI Semester I SDN Lingkok Bunut Kecamatan Janpria Tahun pelajaran 2017/2018?".

\section{Tujuan Penelitian}

Tujuan Penelitian ini adalah untuk Meningkatkan Prestasi Belajar IPS Materi Mengidentifikasikan Benua-Benua dengan Metode Discovery siswa Kelas VI Semester I SDN Lingkok Bunut Kecamatan Janapria Tahun pelajaran 2017/2018.

\section{Manfaat Penelitian}

Hasil PTK dapat bermanfaat bagi guru lain yang memiliki masalah yang sama/serupa sebagai input atau msukan untuk melakukan pemecahan masalah kelas di sekolah lain dalam rangka meningkatkan kualitas proses dan hasil pembelajaran IPS dengan menggunakan model pembelajaran discopery.

\section{LANDASAN TEORI DAN KAJIAN PUSTAKA \\ Model Pembelajaran Discovery (Penemuan)}

Penemuan adalah terjemahan dari discovery. Menurut Sund "discovery adalah proses mental dimana siswa mampu mengasimilasikan sesuatu konsep atau prinsip". Proses mental tersebut ialah mengamati, mencerna, mengerti, mengolong-golongkan, membuat dugaan, menjelaskan, mengukur, membuat kesimpulan dan sebagainya (Roestiyah, 2001:20).

Sedangkan menurut Jerome Bruner "penemuan adalah suatu proses, suatu jalan/cara dalam mendekati permasalahan bukannya suatu produk atau item pengetahuan tertentu". Dengan demikian di dalam pandangan Bruner, belajar dengan penemuan adalah belajar untuk menemukan, dimana seorang siswa dihadapkan dengan suatu masalah atau situasi yang tampaknya ganjil sehingga siswa dapat mencari jalan pemecahan (Markaban, 2006:9).

Model penemuan terbimbing menempatkan guru sebagai fasilitator. Guru membimbing siswa dimana ia diperlukan. Dalam model ini, siswa didorong untuk berpikir sendiri, menganalisis sendiri sehingga dapat "menemukan" prinsip umum berdasarkan bahan 
atau data yang telah disediakan guru (PPPG, 2004:4)

Model penemuan terbimbing atau terpimpin adalah model pembelajaran penemuan yang dalam pelaksanaanya dilakukan oleh siswa berdasarkan petunjuk-petunjuk guru. Petunjuk diberikan pada umumnya berbentuk pertanyaan membimbing (Ali, 2004:87).

Dari pendapat diatas dapat disimpulkan bahwa model penemuan terbimbing adalah model pembelajaran yang dimana siswa berpikir sendiri sehingga dapat "menemukan" prinsip umum yang diinginkan dengan bimbingan dan petunjuk dari guru berupa pertanyaanpertanyaan yang mengarahkan. ciri utama belajar menemukan yaitu: (1) mengeksplorasi dan memecahkan masalah untuk menciptakan, menggabungkan dan menggeneralisasi pengetahuan; (2) berpusat pada siswa; (3) kegiatan untuk menggabungkan pengetahuan baru dan pengetahuan yang sudah ada.

\section{Pengertian Prestasi Balajar}

Prestasi Belajar atau Hasil Belajar (Achievement) yang merupakan realisasi atau perkara dari kecakapan-kecakapan potensial atau kapasitas yang di miliki seseorang. Berikut merupakan beberapa definisi tantang prestasi belajar menurut beberapa ahli, yaitu: (1) Sumadi Suryabrata, Prestasi Belajar adalah nilai sebagai rumusan yang diberikan guru bidang studi mengenai kemajuan atau prestasi belajar selama masa tertentu. (Sumadi Suryabrata, 1998); (2) Siti Pratini, Prestasi Belajar adalah suatu hasil yang dicapai seseorang dalam melakukan kegiatan belajar. (Siti Pratini, 2005)

Berdasarkan pendapat para ahli tentang Pengertian Prestasi Belajar, maka dapat disimpulkan bahwa Prestasi Belajar adalah hasil yang dicapai atau ditunjukkan oleh peserta didik sebagai hasil belajarnya yang diperoleh melalui pengalaman dan latihan. Hal ini biasanya berupa angka-angka, huruf, serta tindakan yang dicapai masing-masing peserta didik dalam waktu tertentu.

Dari berbagai pengertian tentang prestasi belajar di atas dapat diambil kesimpulan bahwa sebenarnya Prestasi Belajar peserta didik tidak selamanya merupakan gambaran dari kemampuan yang sebenarnya. Dengan demikian Prestasi Belajar di sekolah tidak selalu di wujudkan dengan kecakapan-kecakapan, namun kecakapan itu hanya merupakan sabagian dari unsur pertumbuhan, dan pembentukan dari suatu prestasi belajar.

Suatu aktifitas dapat dikatakan atau dikategorikan Prestasi atau Hasil Belajar apabila memenuhi unsur-unsur sebagai berikut: (1) Adanya perubahan tingkah laku, (2) Perubahan terjadi dari hasil latihan atau pengalaman, (3) Perubahan itu menyangkut beberapa aspek, yaitu aspek Kognitif, Afektif, dan Psikomotorik.

\section{METODE PENELITIAN}

Subjek Penelitian

Subjek Penelitiannya adalah siswa kelas VI SD Negeri Lingkok Bunut yang berjumlah 27 siswa, terdiri dari 12 siswa laki-laki dan 15 siswa perempuan. Karakteristik siswa SDN Lingkok Bunut, keadaan ekonomi rata-rata menengah kebawah karena $75 \%$ wali murid berprofesi sebagai Buruh Tani, Pendidikan wali murid rata-rata tamatan Sekolah Dasar, bahkan masih banyak siswa yang ikut bekerja membantu orang tua mencari napkah dan kecerdasan siswa sangat heterogen.

\section{Prosedur Penelitian}

Kegiatan penelitian ditempuh melalui prosedur yang ditentukan, yaitu melalui empat tahap, yaitu perencanaan pembelajaran, pelaksanaan pembelajaran, observasi dan pencatatan pembelajaran, dan analisis serta refleksi pembelajaran

\section{Perencanaan Tindakan Penelitian}

Perencanaan tindakan penelitian dilakukan berdasarkan hasil orientasi dan identifikasi masalah pengajaran. Kegiatankegiatan yang dilakukan dalam tahap ini adalah : (1) Menelaah kurikulum SD kelas VI Mata pelajaran IPS (2) menyusun Rencana Pelaksanaan Pembelajaran IPS (3) menyusun lembar observasi proses pelaksanaan pembelajaran (4) Membuat LKS (5) Menyusun alat evaluasi.

\section{Pelaksanaan Tindakan Penelitian}

Penelitian ini dalam setiap siklusny dilaksanakan empat tahap yaiu; (1) Perencanaan, (2) Pelaksanaan, (3) Pengamatan, (4) refleksi dan revisi

\section{Pengumpulan Data}

Teknik pengumpulan data yang digunakan dalam penelitian ini terdiri dari 2 teknik, yaitu teknik observasi dan teknik tes.(a) Teknik Observasi, (b) Teknik Tes, tes dilakukan pada akhir kegiatan pembelajaran dengan menggunakan lembar soal.

Alat pengumpulan data yang digunakan dalam penelitian ini adalah; (a) Butir Soal tes sebanyak 5 nomor, (b) Lembar Observasi, yaitu: (1) Observasi terhadap rencana pembelajaran., (2) Observasi terhadap proses pembelajaran., (3) Observasi terhadap hasil yang diperoleh siswa setelah dilakukan tindakan.

Analisa Data 
Teknik analisis data yang digunakan ada yang bersifat kuantitatif dan kualitatif. Data yang diperoleh dikatagorikan dan diklasifikasikan berdasarkan analisis kaitan logisnya, kemudian disajikan secara aktual dan sistematis dalam keseluruhan permasalahan dan kegiatan penelitian.Selanjutnya untuk menganalisis data, hasil tindakan yang dilakukan penulis disajikan secara bertahap sesuai urutan siklus yang telah dilaksanakan, adapun prosedur pengolahan data adalah sebagai berikut :

\section{HASIL PENELITIAN DAN PEMBAHASA Kondisi Awal}

Berdasarkan data Tahun Pelajaran 2017/2018, jumlah siswa SDN Lingkok Bunut 148 orang siswa terdiri dari 69 laki-laki dan 79 perempuan, keadaan ekonomi wali murid rata-rata menengah kebawah karena $75 \%$ wali murid berprofesi sebagai Buruh Tani, Pendidikan wali murid rata-rata tamatan Sekolah Dasar, bahkan masih banyak siswa yang ikut bekerja membantu orang tua mencari napkah dan kecerdasan siswa sangat heterogen. Siswa Kelas VI SD Negeri Lingkok Bunut pada semester I terdiri dari 27 siswa yaitu 12 laki-laki dan 15 Perempuan. Aktivitas siswa dalam pembelajaran Ilmu Pengetahuan Sosial, siswa kurang antusias dalam menghadapi pelajaran,terbukti dari hasil pra siklus hanya 13 siswa $(48,15 \%)$ yang memperoleh nilai $\geq 70$ dimana angka KKM yang ditetapkan 70,sedangkan 14 siswa $(51,85 \%)$ memperoleh nilai $\leq 69$, dengan nilai rata rata 58,52 , nilai terendah 40 dan nilai tertinggi 80 , hal ini salah satu penyebabnya adalah guru tidak menggunakan Model pembelajaran yang tepat.

\section{Siklus I}

Proses pembelajaran pada Siklus I meliputi kegiatan guru dalam mengajar, dan siswa dalam belajar dapat dilihat pada tabel Dari tabel dapat kita lihat Siswa yang mendapat nilai di atasyang memperoleh nilai $\geq 70$ sebanyak 18 Siswa, atau 66,67 \% sedangkan yang memperoleh nilai $\leq 69$ sebanyak 9 Siswa atau $33,33 \%$ dari 27 Siswa dengan nilai rata rata 70 dengan nilai terendah 50 dan nilai tertinggi 80 .

\section{Siklus II}

Berdasarkan hasil analisis data dapat dijelaskan bahwa Siswa yang mendapat nilai $\geq 70$ sebanyak 24 Siswa, atau 88,89\% sedangkan nilai $\leq 69$ sebanyak 3 Siswa atau $11,11 \%$ dari 27 Siswa,dengan nilai rata rata 76,48 , dengan nilai terendah 60 dan nilai tertinggi 90, ini disebabkan karena pemahaman siswa terhadap materi semakain meningkat.
Berdasarkan hasil penelitian pada Siklus 2 maka hasil refleksi selama kegiatan pada penelitian yang dimulai dari persiapan, pelaksanaan dan penilaian/Evaluasi dianggap sudah berhasil, hal ini berdasarkan tingkat kemampuan siswa yang cukup baik.

Tabel ;Aktivitas Belajar Siswa kelas VI Dalam Pembelajaran IPS

\begin{tabular}{|c|c|c|c|c|c|c|}
\hline \multirow{2}{*}{ No } & \multirow{2}{*}{$\begin{array}{l}\text { KeterflibatanPeserta } \\
\text { Didili Dalam } \\
\text { Pembelajiran }\end{array}$} & \multirow{2}{*}{$\begin{array}{l}\text { Sebelum } \\
\text { Perbailan } \\
\text { Sumlah } \\
\text { Siswa }\end{array}$} & \multicolumn{2}{|c|}{ Siklus I } & \multicolumn{2}{|c|}{ Sillus II } \\
\hline & & & $\begin{array}{l}\text { Jumlah } \\
\text { Siswra }\end{array}$ & $\%$ & $\%$ & $\begin{array}{l}\text { Jumlah } \\
\text { Siswa }\end{array}$ \\
\hline 1 & Terlibat Actif & 3 & 19 & $70,37 \%$ & 24 & $88,89 \%$ \\
\hline 2 & Terlibat Pasif & 4 & 6 & $22,22 \%$ & 2 & $7,41 \%$ \\
\hline \multirow[t]{2}{*}{3} & Tidak Terlibat & 20 & 2 & $7,41 \%$ & 1 & $3,70 \%$ \\
\hline & Jumlah & 27 & 27 & $100 \%$ & 17 & $100 \%$ \\
\hline
\end{tabular}

Berdasarkan tabel diatas terlihat bahwa jumlah siswa dan persentase siswa yang terlibat aktif dalam pembelajaran sebelum perbaikan pembelajaran menunjukkan adanya kenaikkan, sebelum perbaikan pembelajaran siswa yang terlibat aktif hanya 3 orang $(11,11 \%)$ kemudian naik pada siklus I menjadi 19 orang $(70,37 \%$ ).Dan pada siklus II naik menjadi 24 orang $(88,89 \%)$. Hal ini menunjukkan bahwa aktivitas belajar siswa dalam pembelajaran IPS mengalami peningkatan.

Tabel ;Hasil Belajar Siswa dalam Pembelajaran IPS

\begin{tabular}{|c|c|c|c|c|c|c|c|}
\hline \multirow{2}{*}{$\begin{array}{c}\text { Interval } \\
\text { Nilai }\end{array}$} & \multicolumn{2}{|c|}{ Sebelum Perbaikan } & \multicolumn{2}{c|}{ Siklus I } & \multicolumn{2}{c|}{ Siklus II } & \multirow{2}{*}{ Kategori } \\
\cline { 2 - 7 } & Frekluensi & Persen & Frekuensi & Persen & Frekluensi & Persen & \\
\hline $80-100$ & 2 & $7,41 \%$ & 4 & $14,81 \%$ & 22 & $81,48 \%$ & Tuntas \\
\hline $70-79$ & 11 & 40,74 & 14 & 51,85 & 2 & 7,41 & Tuntas \\
\hline $60-69$ & 3 & $11,11 \%$ & 5 & $18,52 \%$ & 3 & $11,11 \%$ & tidaki Tuntas \\
\hline $40-59$ & 11 & $40,74 \%$ & 4 & $11,11 \%$ & 0 & $0 \%$ & Tidak Tuntas \\
\hline 0.39 & 0 & $0 \%$ & 0 & $0 \%$ & 0 & $0 \%$ & Tidalak Tuntas \\
\hline
\end{tabular}

Dari data di atas dapat terlihat bahwa hasil belajar siswa cenderung meningkat. Sebelum perbaikan pembelajaran siswa yang telah tuntas belajar sebanyak 13 orang siswa $(48,15 \%)$ pada siklus I bertambah menjadi 18 orang siswa $(66,67 \%)$ dan pada siklus II menjadi 24 orang siswa $(88,89 \%)$.

Tabel ;Lembar Aktivitas Siswa dalam Diskusi Kelompok 


\begin{tabular}{|c|c|c|c|c|c|}
\hline \multirow[t]{2}{*}{ No } & \multirow[t]{2}{*}{ Aspek yang Diamati } & \multicolumn{2}{|c|}{ Sitlus I } & \multicolumn{2}{|c|}{ Sildus II } \\
\hline & & Freluentis & Persentiase & Frekuenlis & Persentitase \\
\hline 1. & Mengajukan Pendapat & 5 & $18,52 \%$ & 13 & $48,15 \%$ \\
\hline 2. & Aktif dalam Diskus' & 6 & $22,22 \%$ & 14 & $51,85 \%$ \\
\hline 3. & Menjawab Pertanyaan & 6 & $22,22 \%$ & 15 & $55,56 \%$ \\
\hline 4. & $\begin{array}{l}\text { Membantu Mengerjacan } \\
\text { Tugass }\end{array}$ & 11 & $40,74 \%$ & 27 & $100 \%$ \\
\hline
\end{tabular}

Dari tabel diatas terlihat adanya peningkatan aktivitas diskusi kelompok mengerjakan LKS.Dalam mengajukan pendapat pada siklus I sebanyak 5 orang $(18,52$ $\%)$,dan pada siklus II meningkat menjadi 13 orang $(48,15 \%)$.Siswa yang aktif dalam diskusi juga meningkat yaitu pada siklus I sebanyak 6 orang $(22,22 \%)$ dan meningkat pada siklus II meningkat menjadi 14 orang $(51,85 \%)$.Kemudian aktivitas menjawab pertanyaan juga meningkat pada siklus I sebanyak 6 orang $(22,22 \%)$ dan pada siklus II meningkat menjadi 15 orang $(55,56$ $\%)$.Kemudian akyivitas membantu mengerjakan tugas juga meningkat yaitu sebanyak 11 orang pada siklus I kemudian sebanyak 27 orang (100\%)pada siklus II.

\section{KESIMPULAN DAN SARAN}

Pada pra Siklus jumlah siswa yang tidak tuntas dalam mengikuti pembelajaran 13 orang siswa. Setelah dilaksanakan perbaikan pembelajaran pada Siklus 1 nampak sekali peningkatan hasil belajar siswa yaitu sebesar $66,67 \%$, atau 18 siswa, sudah tuntas dan 9 siswa masih belum tuntas. Pada siklus 2 mengalami peninkatan secara signifikan dimana siswa yang tuntas belajar sebesar $88,89 \%$ atau 23 orang siswa dan yang belum tuntas sebanyak 3 orang siswa atau $11,11 \%$. Berdasarkan uraian pembahasan dan hasil penelitian di atas mulai Siklus 1 sampai siklus 2 mengenai penggunaan model pembelajaran discopery, dapat peneliti simpulkan bahwa: 1. Dengan menggunakan pembelajaran discopery, mampu meningkatkan prestasi belajar siswa Kelas VI SD Negeri Lingkok Bunut pada materi kenampakan alam. 2. Melalui pembelajaran discopery, siswa dapat lebih aktif dalam kegiatan belajar

Berdasarkan kesimpulan di atas serta hasil perbaikan dan pembelajaran, agar kegiatan belajar mengajar Ilmu Pengetahuan Sosial yang membahas mengenai "Kenampakan Alam" anak lebih aktif, kreatif dan memberikan hasil yang optimal bagi siswa. Maka ada beberapa saran yang dapat disampaikan sebagai berikut: 1. Dalam kegiatan pembelajaran IPS sebaiknya guru menggunakan model pembelajaran Discopery, karena dengan model pembelajaran tersebut dapat meningkatkan prestasi belajar siswa. 2. Guru hendaknya menerapkan pembelajaran discopery, karena dapat mengaktifkan siswa dalam pembelajaran.

\section{DAFTAR PUSTAKA}

Roestiyah. (2001). Strategi Belajar Mengajar. Jakarta: Rineka Cipta.

Markaban, (2006 ).Penelitian Tindakan Kelas. Jakarta: bumi Aksara.

Bell. 1978. 5. Teaching Mathematics: Developing as A Reflective Secondary Teacher

Budiningsih, Asri. (2005). Belajar dan Pembelajaran. Jakarta: PT. Rineka Cipta.

Syah. 2004. Psikologi Pendidikan dengan Pendekatan Baru. Bandung: PT Remaja

Taba dalam Affan..(1990).Generalisasi. Banguntapan Jogjakarta:

Djamarah. (2002). Teori Motivasi, edisi 2 (ed2), Jakarta : PT. Bumi Aksara.

Voigt, R., 1994, Buku Pelajaran Teknologi Farmasi, diterjemahkan oleh: Soendani.

Slavin, Robert E., (1994). Science Instruction ... Rineka Cipta. .

Ratumanan. 2002.Analisis Data Kualitatif (Buku. Sumber Tentang Metodemetode Baru). Jakarta: UIP. ...

Marzano. 1992.Pembelajaran Kooperatif. Yogyakarta : Pustaka Pelajar.

Dahrendorf, Ralf. 1998. ... S. 2000. Filsafat Ilmu Suatu Pengantar Populer. Jakarta: Pustaka Sinar Harapan

Sumadi Suryabrata. (1998). Psikologi Pendidikan. Jakarta: Raja Grafindo

Siti Pratini. (2005). Psikologi Pendidikan. Yogyakarta: Studing

Bukhari M. (1983). Teknik-Teknik Evaluasi Dalam Pendidikan. Bandung: Jemmars

Winkel WS. (1989). Psikologi Pengajaran. Jakarta: Gramedia 